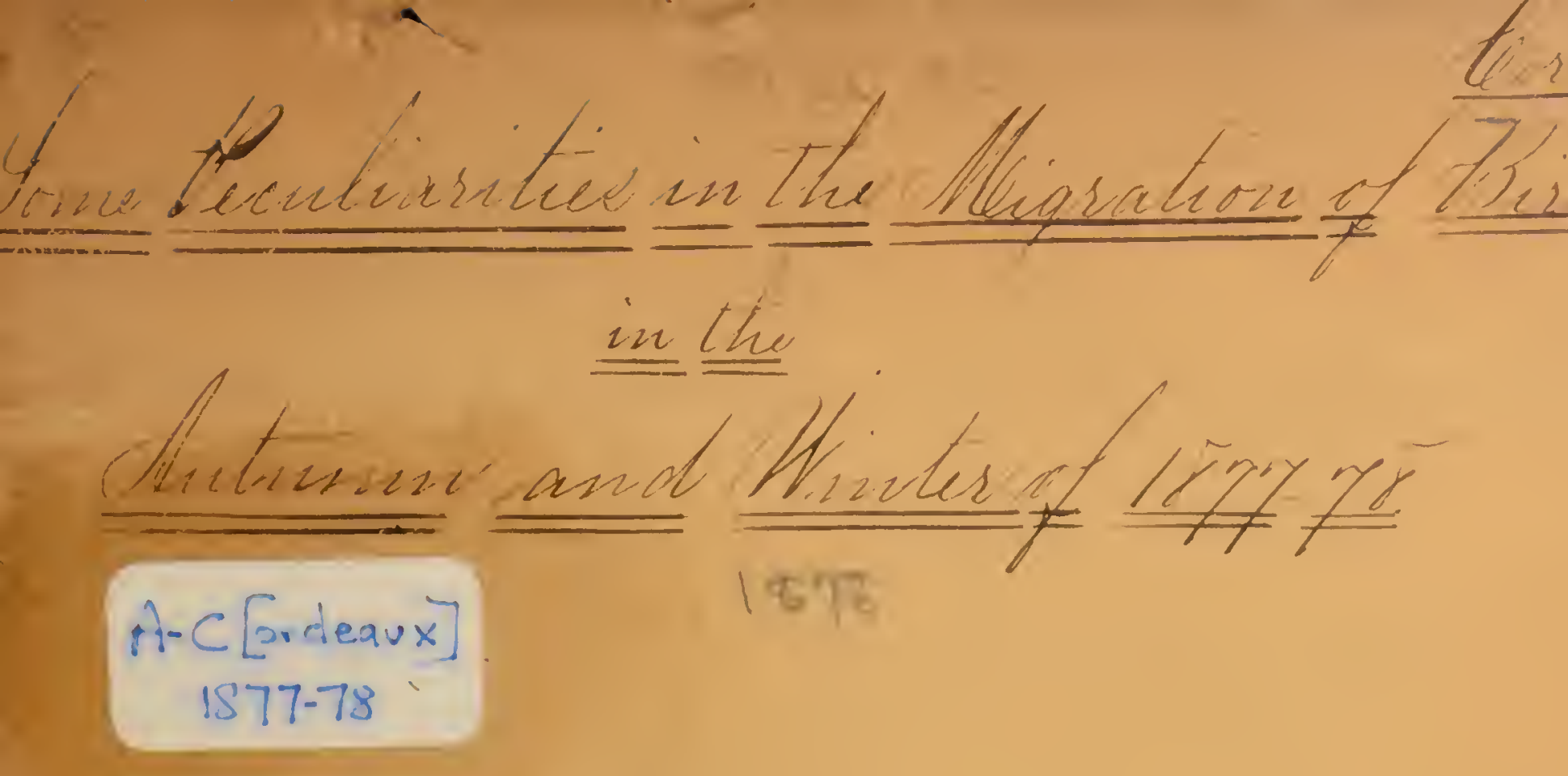







[From the QUarterly Journal of tile Meteorological SOCIETY; for July, 1878.]

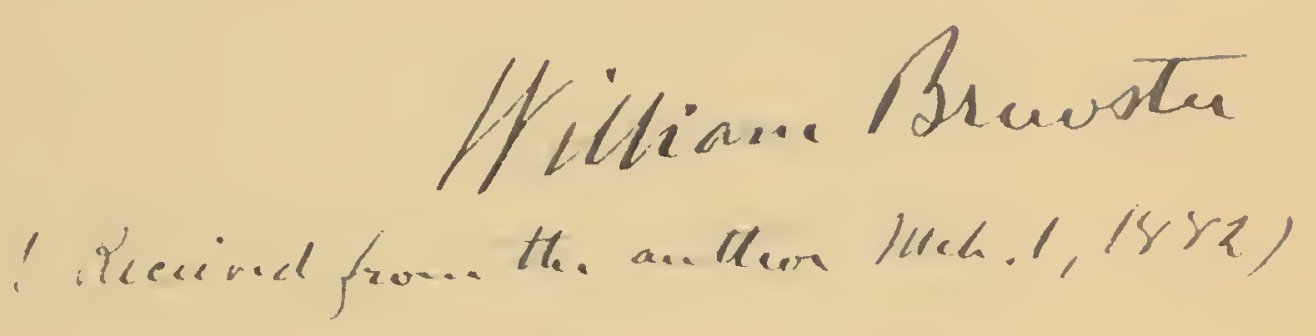

\section{ON SOME PECULIARITIES}

IN THE

\section{MIGRATION OF BIRDS}

IN THE

\section{AUTUNIN AND WINTER OF 187\%-98.}

$\mathrm{BY}$

J O H N C OR D E A UX.

THE Autumn and Winter of $1877-78$ have been remarkable for their extreme mildness. On the north-east coast of England, from the middle of September to the end of November, the prevailing winds were from points varying from WNIV to SSE, and there was not a single gale or eren a strong breeze 
during that period from $\mathrm{N}, \mathrm{NE}$, or $\mathrm{E}$. This long continuance of favourable passage winds for the birds has been apparent on our east coast by the general scarcity of the usual autumnal immigrants arriving from the North of Europe. With few exceptions they have passed overhead without showing themselves, or alighting for temporary repose. This is always the case in a favourable migrating season. It is a well-ascertained fact that birds migrate the best, and with the greatest ease to themselves, against a moderate head wind, or one a "fow points free." There is also during the present season another reason for the scarcity of immigrants, the unusually mild winter in Scandinavia having induced many to remain long after their usual time for leaving the north. So that the migration of any particular species, which on a whole extends over a period of from four to six weeks, has this season been greatly prolonged, and presented much more of a desultory character, than is the case in average years.

In America, or rather the Nearctic region, the heat and cold being more extreme, the movements of the birds are more sudden and complete than in the Western Palæarctic regions, where the autumnal migratory movement is carried on more gradually, although, normally, when once commenced it goes on uninterruptedly, till the great movement to the south is completed, towards the middle or end of November. In the present season of 1877-78 this southward flow of the bird tide has been much more protracted than is ustually the case; as an illustration, I will take, out of several, the cases of the blackbird, fieldfare, and woodcock. The first flights of the former species arrived on our north-east coast after the great gale from the SW on the night of October 14th. There was again a great influx of blackbirds coming from the north on or about the 26th of November, and the tro following nights; this immigration extended, as I have ascertained from the notes kindly supplied to me by the principals of lighthouses in our northeast districts, nearly the whole length of the Yorkshire coast-line, also in north-east Lincolnshire. Mr. Gätke, of Heligoland, an ornithologist having a European celebrity, writing to me from that island, January 21st, says :"For some weeks we have had every day some woodcocks, also some blackbirds." Again later, "February 2nd, wind $\mathrm{E}$ in the morning, $\mathrm{N}$ and $\mathrm{N}$ by $\mathrm{E}$ in the evening. Turdus merula, from 20 to 40 , as I fancy from the north."

The first flight of fieldfares arrived in north-east Lincolnshire from the 18th to the end of October. Since this date they have come in at interrals during the winter. As late as the end of January, Mr. Gätke writes from Heligoland: "January, night from 27th to 28th. Turdus pilaris, countless flights." Woodcocks liave been exceptionally scarce, my first notice on the north-east coast was from Seaton Snook, Durham, October 5th; all through January some appear to have touched daily at Heligoland.*

Although the weather has been on the whole remarkably and abnormally mild in the north of Europe, we have had at intervals some short bursts of

* Great numbers of woodcocks passed the No. 5 Tees Buoy Lightship on the 20th and 21 st of October. Wind W and STV, with rain. 
severe weather, frost and snow, lasting only a few days. The effect of these rapid variations of temperature has been to drive the laggards in the north southward, not gradually, but as it were, in sudden rushes, corresponding with the outbreaks of bad weather in the north. There was one such rush on October 27th. A correspondent writing from one of the floating lightships at the moutl of the Tees says:-" 27 th, strong breeze and cloudy; barometer at noon $29 \cdot 60 \mathrm{in}$., thermometer $58^{\circ}$. Two woodcocks and great many crows this day; large flocks of lapwings came in from east all day, also large flocks of wild ducks and a great variety of other small birds. They appear to come in from ESE. I never observed so many birds come over in one day before."

Again, Mr. Gätlie, writing from Heligoland, November 14th, says:- "Wind SW, but moderate, and although cloudy, there is no rain. During the night there was a great rush of thrushes, larks, lapwings, robins, and fire-crested wrens (both Reguli), intermixed with lots of other birds. . . What do we read out of this? That there is in the north an appearance of winter driving off the migranes helter-skelter."

Again, I may instance the great rush of fieldfares over Heligoland on the nights of January 27th and 28th.

At the same time Mr. Gätle sends the following note:- "Colymbus septentrionalis, 29th January, from 9 a.m. and earlier to 4 p.m., an uninterrupted stream of birds from NNE to SSW, passing to the east of this island, constantly from eight to twelve in focus of glass."

This extraordinary rush of red-throated divers, coming doubtless from Scandinarian waters, was caused by the same outburst of severe weather which drove the fieldfares southward on the nights of the 27 th and 28 th. We had in England some severe weather from the 23rd to the 27th of January coming from the WNW and NW, frost and snow.

The red-throated divers may have delayed their movements southward in consequence of the unfrozen state of the Scandinavian fiords. Another reason causing the stay of these and other large dirers in the north, may have been the extraordinary infiux of herrings into the Kattegatt, and from thence into the fiords. This is more remarkable when we consider that the herring fishery has been practically extinct on this coast through the disappearance of the fish since the year 1808.

Fear of trespassing on valuable space induces me to bring these remarks to a conclusion. I think, however, enough has been said to show the abnormal character of the season, with reference to the autumnal migration of birds from the north of Europe to the south. 






